\title{
The distribution history of the Amur brown lemming (Lemmus amurensis) in the Late Pleistocene - Holocene in the southern Far East of Russia
}

\begin{abstract}
Mikhail P. Tiunov* \& Valeria E. Panasenko
ABSTRACT. Fossil bone remains of Amur (Lemmus amurensis) and wood (Myopus schisticolor) lemmings were obtained from the Late Pleistocene-Holocene deposits at the Medvezhiy Klyk Cave (Primorski Kray). These species were differentiated based on proportions of $\mathrm{M}^{3}$. Bone remains of Amur lemming occur throughout the exposed thickness of loose deposits in the Medvezhiy Klyk Cave from the depth of 5.4 $\mathrm{m}$ and almost to the surface. The occurrence confirms a hypothesis of a relict status of recent Amur lemming and its wider distribution in the Late Pleistocene.
\end{abstract}

KEY WORDS: distribution, Holocene, Late Pleistocene, Lemmus amurensis, Myopus schisticolor, Far East, Russia.

Mikhail P. Tiunov [tiunov@ibss.dvo.ru] and Valeria E. Panasenko, Institute of Biology and Soil Science Far East Branch of the Russian Academy of Sciences, Vladivostok 690022, Russia.

\section{К истории распространения амурского лемминга (Lemmus amurensis) в позднеплейстоцен - голоценовом времени на территории юга Дальнего Востока России}

\author{
М.П. Тиунов, В.Е. Панасенко
}

РЕЗЮМЕ. В позднеплейстоцен-голоценовых отложениях пещеры Медвежий Клык (Приморский край) обнаружены костные остатки амурского и лесного леммингов. Определение этих видов проводилось по $\mathrm{M}^{3}$. Встречаемость костных остатков амурского лемминга по всей толще вскрытых рыхлых отложений пещеры Медвежий Клык, начиная с глубины 5,4 м и почти до поверхности, подтверждает гипотезу о реликтовости современных амурских леммингов и более широком распространении их в позднем плейстоцене.

КЛЮЧЕВЫЕ СЛОВА: распространение, голоцен, поздний плейстоцен, Lemmus amurensis, Myopus schisticolor, Дальний Восток, Россия.

The Amur lemming (Lemmus amurensis Vinogradov) is a rare relict species that is widely distributed from Transbaikalia and the Amur River to Kamchatka and the Verkhoyansk Range (Gromov \& Erbaeva, 1995; Andreev et al., 2005). The habitats of the species are typically situated in forest wetlands and highlands, and their basic food consists of green mosses. Fossils of the Amur brown lemming were only known from the middle and upper Pleistocene of the Baikal region (Abramson, 1993; Khenzykhenova, 2001).

Lemming fossils were obtained from deposits in the Medvezhiy Klyk Cave (located at the crest of the Lozovy Range in the Partizansk District of Primorski Kray) (Tiunov \& Panasenko 2007). Examination of third upper molars revealed the presence of two morphological types of lemmings (tribe Lemmini): Lemmus and Myopus. Molars of Lemmus are comparatively more elongated and narrow, whereas the grinding surface in $\mathrm{Myo}$ pus is relatively broad and short. As has been shown previously, researchers can use molar proportions to identify fossil lemming species (Agadzhanyan, 1972; Smirnov et al., 1997; Chaline et al., 1989).

Currently, no lemming species are known in the area near the Medvezhiy Klyk Cave. The southern boundary of the wood lemming (Myopus schisticolor (Lilljeborg)) range in Primorski Kray lies $300 \mathrm{~km}$ to the north of the cave (Kostenko, 2000). The nearest habitat of the Amur brown lemming is in the Amur Oblast at the headwaters of the Zeya River. In addition to these two species, there are two more Lemmus species in the Far East with similar teeth structure: the Siberian brown lemming (L. sibiricus (Kerr)), found on Wrangel Island, and the North American brown lemming (L. trimucronatus (Richardson)), widely spread from the right bank of the Lower Kolyma to the eastern part of the Chukchi Peninsula and the Anadyr Lowlands. The ranges of these species, which inhabit tundra landscapes, are quite distant from the area of the study. The most recent explanation for this is that approximately $25-15 \mathrm{ka}$ ago, the brown lemming moved westward into the Chukchi 


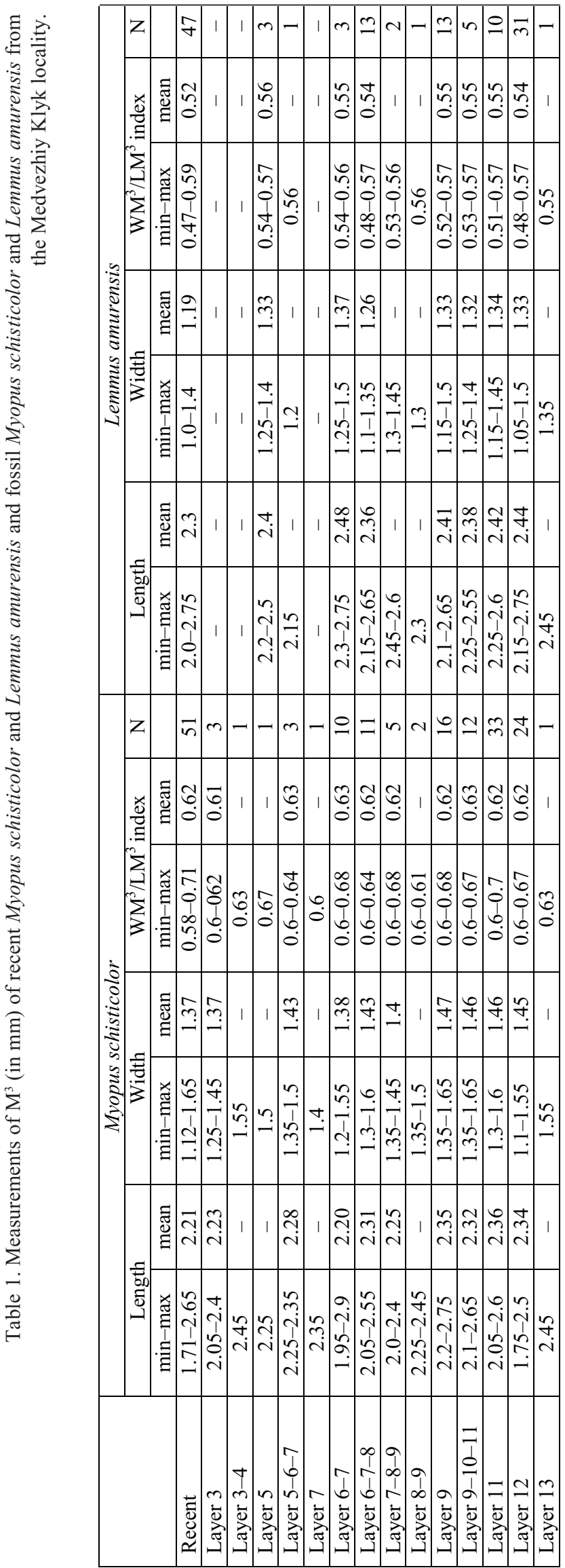




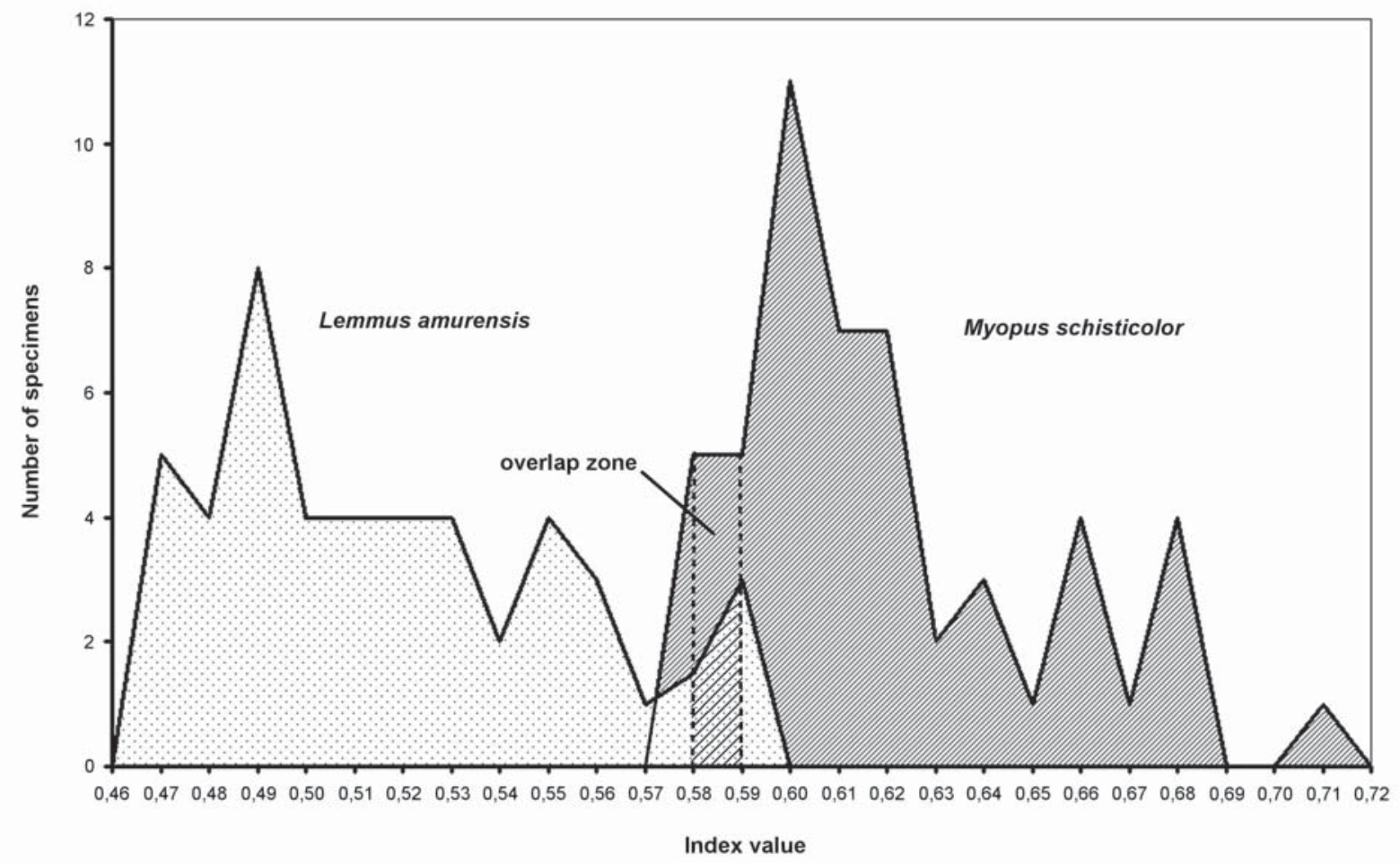

Figure 1. Distribution of width/length ratio (index) values $\left(\mathrm{WM}^{3} / \mathrm{LM}^{3}\right)$ in recent Lemmus amurensis and Myopus schisticolor. The overlap zone indicated stands for revealed fossil molars of intermediate morphology.

Peninsula and populated it up to the mouth of the Kolyma River (Chernyavsky et al., 1993). Therefore, of the known lemming species, the ones most likely to be found among the bone remains in southern Primorie are the wood lemming and the Amur lemming.

In this report, we provide data on size of $\mathrm{I}^{3}$ in the modern Amur and wood lemmings. This work was based on material collected by the Zoological Institute RAS and the Institute of Biology and Soil Science FEB RAS. Lower right molars of 51 of recent wood lemmings from the Khabarovski Kray, Amurskaya Oblast and Sakhalin Island were measured. Forty seven studied specimens of Amur lemmings originated from the Amurskaya Oblast, Yakutia, and the Kamchatka Peninsula. MBS-10 binocular microscope with a micrometer eyepiece was used for the measurements. Measurements included the length and width of the third upper molars $\left(\mathrm{LM}^{3}\right.$ and $\left.\mathrm{WM}^{3}\right)$. Length to width ratio $\left(\mathrm{WM}^{3} /\right.$ $\mathrm{LM}^{3}$ ) was calculated too (Table 1).

This study made it apparent that Amur and wood lemmings cannot be differentiated based on the absolute dimensions of the grinding surface $\left(\mathrm{I}^{3}\right)$, as the dimensions almost completely overlapped. In contrast, the proportions (i.e., width to length ratio of the grinding surface of $\mathrm{M}^{3}$ ) showed marked distinctions (Fig. 1).

Using 263 third upper molars excavated from deposits of the Medvezhiy Klyk Cave, 123 teeth were assigned to the lemming species $M$. schisticolor $\left(\mathrm{WM}^{3} /\right.$ $\mathrm{LM}^{3}=0.60-0.68$ ), and 83 teeth were identified as $L$. amurensis $\left(\mathrm{WM}^{3} / \mathrm{LM}^{3}=0.48-0.57\right)$. The differences in proportion between them are clear from Figure 2. For the remaining 57 teeth, the width/length ratio ranged between 0.58 and 0.59 . These teeth can represent either M. schisticolor or L. amurensis, and their identification to the species is impossible for the time being.

The teeth of wood and Amur lemmings were distributed vertically across almost the entire depth of exposed unconsolidated deposits in the Medvezhiy Klyk Cave, from a depth of $5.4 \mathrm{~m}$ up to the surface. Based on lithologic features, cave deposits have been divided into 13 layers. Deposits at the depth range of 1.08-1.18 $\mathrm{m}$ (layer 7) were radiocarbon dated (based on the bear bone) to 13.79-14.2 ka cal. BP (GIN-13479). As the layers bedding was flat and semi-steep, and the ground was excavated in beds with $5-10 \mathrm{~cm}$ increment, some samples represent mixed material from neighbouring levels (Table 1).

Based on the radiocarbon dating and faunal composition, layers 3-5 were assigned to Holocene, and layers 6-13, to the Late Pleistocene. In morphotypes present, Holocene and Late Pleistocene lemmings do not differ from modern lemmings. In size, however, they are slightly larger than modern lemmings, similar to Pleistocene lemmings from the Baikal region (Khenzykhenova, 2001).

Analysis of the obtained material was objective enough to suppose that the wood lemming inhabited the location for the entire period under investigation, ex- 


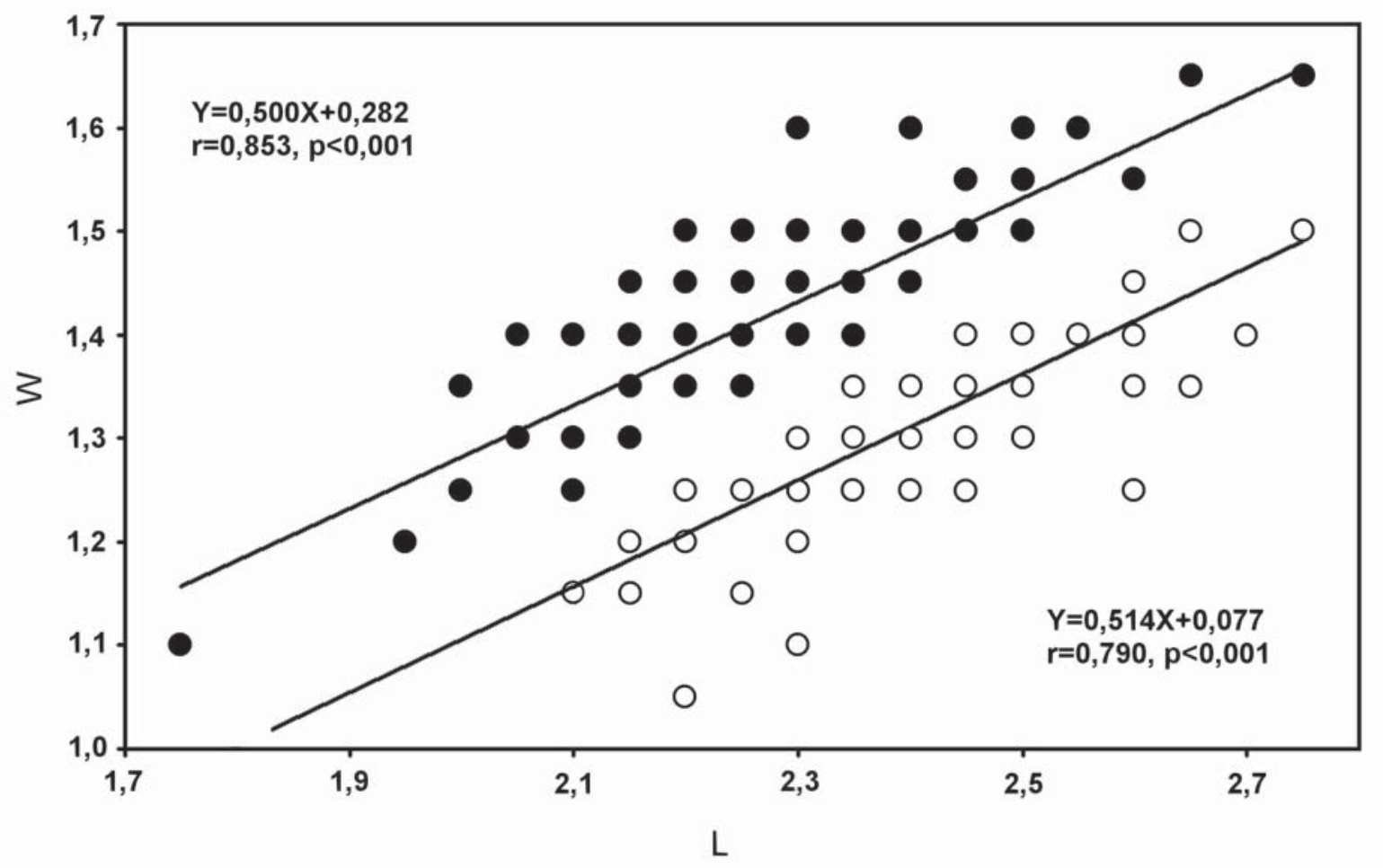

Figure 2. Scatter diagram of occlusal length (L) and width (W) of $\mathrm{M}^{3}$ in fossil Lemmus amurensis $(\bigcirc)$ and Myopus schisticolor ( ) from the Medvezhiy Klyk Cave.

cept the last several centuries. Our data shows that the Amur lemming is present in Late Pleistocene and early Holocene deposits and that this species disappeared from the area of study by the beginning of the middle Holocene. The relict nature of the recent Amur lemmings (Chernyavsky et al., 1980) and their wider dispersion in the Late Pleistocene is confirmed.

ACKNOWLEDGEMENTS. We thank L.L. Voita and F.N. Golenishchev (Zoological Institute RAS, St.Petersburg) for useful cooperation. This work was supported by the research grant of the Far East Division of the Russian Academy of Sciences \# 09-III-A-06-183.

\section{References}

Abramson N.I. 1993. [The genus Lemmus in Eurasia in the Late Cenozoic] // Proceedings of the Zoological Institute RAS. Vol.249. P.146-157 [in Russian, with English summary].

Agadzhanyan A.K. 1972. [Rodents from Pleistocene deposits of the Mammoth Mountain] // Teriofauna of the Pleistocene. M.: Moscow State University. P.24-69 [in Russian].

Andreev A.V., Dokuchaev N.E., Krechmar A.V., Chernyavsky F.B. 2005. [Terrestrial vertebrates of North-East Russia: annotated catalog of species distribution and biology]. IBPN FEB RAS. Magadan: NESC FEB RAS. 315 p. [in Russian].
Chernyavsky F.B., Krivosheev V.G., Revin Yu.V., Khvorostyanskaya \& Orlov V.N. 1980. [On distribution, taxonomy and biology of the Amur Lemming (Lemmus amurensis)] // Zoologicheskii Zhurnal. Vol.59. No.7. P.1077-1084 [in Russian, with English summary].

Chernyavsky F.B., Abramson N.I., Tsvetkova A.A., Anbinder E.M. \& Kurysheva L.P. 1993. [On systematics and zoogeography of true lemming of the genus Lemmus (Rodentia, Cricetidae) of Beringia.] // Zoologicheskii Zhurnal. Vol.72. No.8. P.111-122 [in Russian, with English summary].

Gromov I.M. \& Erbaeva M.A. 1995. [The Mammals of Russia and Adjacent Territories. Lagomorphs and Rodents]. Sankt Peterburg: Zoologicheskii Institut RAN. 522 p. [in Russian].

Khenzykhenova F.I. 2001. Fossil lemmings (Rodentia: Cricetidae) in the Baikal region // Lynx (Praha), n.s. Vol.32. P.155-169.

Kostenko V.A. 2000. [Rodents (Rodentia) of the Russian Far East]. Vladivostok: Dalnauka. 210 p. [in Russian].

Chaline J., Brunet-Lecomte P., Brochet G. \& Martin F. 1989. Les lemmings fossiles du genere Lemmus (Arvicolidae, Rodentia) dans le Pléistocène de France // Geobios. Vol. 22. No.5. P.613-623.

Smirnov N.G., Golovachev I.B., Bachura O.P., Kuznetsova I.A. \& Cheprakov M.V. 1997. [Intricate cases of identification of some rodent molars from the Late Pleistocene and Holocene deposits in the tundra regions of North Eurasia] // Materials of history and modern fauna 
from the North of the West Siberian. Chelyabinsk: IPAE UD RAN. P.60-90 [in Russian, with English summary].

Tiunov M.P. \& Panasenko V.E. 2007. [New site of the bone rests of vertebrate animals in Late Pleistocene and Ho- locene deposits of the south of Primorski Krai] // Theriofauna of Russia and adjacent territories (VIII symposium of the Theriological Society). Matherials of the International Conference 31 January - 2 February 2007. Moscow : KMK Sci. Press Ltd. P.494 [in Russian]. 